\title{
Article \\ Prevalence of Antibiotic-Resistant Escherichia coli Isolated from Swine Faeces and Lagoons in Bulgaria
}

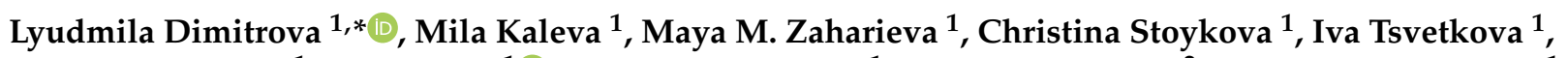 \\ Maya Angelovska ${ }^{1}$, Yana Ilieva ${ }^{1}$ (1), Vesselin Kussovski ${ }^{1}$, Sevda Naydenska ${ }^{2}$ and Hristo Najdenski ${ }^{1}$ \\ 1 The Stephan Angeloff Institute of Microbiology, Bulgarian Academy of Sciences, 26 Akad. G. Bonchev Str., \\ 1113 Sofia, Bulgaria; milakalevavet@abv.bg (M.K.); zaharieva26@yahoo.com (M.M.Z.); \\ christinastoikova98@abv.bg (C.S.); i.likovska@abv.bg (I.T.); mgatzovska@gmail.com (M.A.); \\ illievayana@gmail.com (Y.I.); vkussovski@gmail.com (V.K.); hnajdenski@gmail.com (H.N.) \\ 2 University Multiprofile Hospital for Active Treatment Alexandrovska, Medical University, \\ 1 Georgy Sofiiski Str., 1431 Sofia, Bulgaria; sevda.naydenska@abv.bg \\ * Correspondence: lus22@abv.bg; Tel.: +359-2979-3161
}

\section{check for} updates

Citation: Dimitrova, L.; Kaleva, M.; Zaharieva, M.M.; Stoykova, C.;

Tsvetkova, I.; Angelovska, M.; Ilieva, Y.; Kussovski, V.; Naydenska, S.;

Najdenski, H. Prevalence of

Antibiotic-Resistant Escherichia coli Isolated from Swine Faeces and Lagoons in Bulgaria. Antibiotics 2021, 10, 940. https://doi.org/10.3390/ antibiotics 10080940

Academic Editor: Carmen Losasso

Received: 6 July 2021

Accepted: 30 July 2021

Published: 4 August 2021

Publisher's Note: MDPI stays neutral with regard to jurisdictional claims in published maps and institutional affiliations.

Copyright: (c) 2021 by the authors. Licensee MDPI, Basel, Switzerland. This article is an open access article distributed under the terms and conditions of the Creative Commons Attribution (CC BY) license (https:// creativecommons.org/licenses/by/ $4.0 /)$.

\begin{abstract}
Antimicrobial resistance (AMR) is a worldwide health problem affecting humans, animals, and the environment within the framework of the "One Health" concept. The aim of our study was to evaluate the prevalence of pathogenic strains of the species Escherichia coli (E. coli), their AMR profile, and biofilm-forming potential. The isolated strains from three swine faeces and free lagoons (ISO 16654:2001/Amd 1:2017) were confirmed using Phoenix M50 and 16S rDNA PCR. The antibiotic sensitivity to 34 clinically applied antibiotics was determined by Phoenix M50 and the disc diffusion method, according to the protocols of the CLSI and EUCAST. We confirmed the presence of 16 E. coli isolates, of which $87.5 \%$ were multi-drug-resistant and $31.25 \%$ performed strong biofilms. The possibility for the carrying and transmission of antibiotic-resistance genes to quinolones ( $q n r$ ), aminoglycosides (aac(3)), $\beta$-lactamase-producing plasmid genes ampC, and blaSHV/blaTEM was investigated. We confirmed the carrying of blaSHV/blaTEM in one and ampC in seven isolates. The strains were negative for the virulence genes (ETEC (LT, STa, and F4), EPEC (eae), and STEC/VTEC (st $x$ and st $x 2$ all)). The results should contribute to the development of effective measures for limitation and control on the use of antibiotics, which is a key point in the WHO action plan.
\end{abstract}

Keywords: Escherichia coli; swine faeces and lagoons; antibiotic resistance; PCR methods; Phoenix M50; biofilms

\section{Introduction}

Antimicrobial resistance (AMR) is a global public health challenge mainly caused by the widespread use of antibiotics in human and veterinary medicine for over 60 years. It is reported that deaths caused by AMR could increase from 700,000 in 2014 to 10 million by 2050 [1].

The use of antibiotics in animal husbandry has triggered the emergence and dissemination of antibiotic-resistant bacteria and genes for antibiotic resistance (GAR) from livestock farms to the surrounding environment. Different fractions of animal waste, such as swine manure or wastewater, are routinely applied to the fertilization of agricultural land in many countries. However, this waste has become a reservoir of resistant bacteria and various antibiotic residues that remain active in the soil from 20-30 to 40-60 cm depth for long periods of time via long-term manure application and transfer into groundwater by lagoons $[2,3]$. Their presence exerts a selective pressure on microorganisms and changes the microbial communities through the elimination of sensitive strains and increases the chances of survival for those containing GAR [4,5]. Resistant bacteria and their genetic determinants, such as plasmids, transposons, integrons, and genetic islands, can be spread and exchanged in different ways [6]. When bacteria come into contact with others, they 
exchange genetic determinants of resistance through horizontal gene transfer [7]. The path of distribution by transposons and plasmids between pathogenic and non-pathogenic bacteria in the environment, including GAR, is the most common along the food chain and the most important for the transmission of genetic variability [8,9]. Therefore, in addition to measures to reduce the use of antibiotics in animal husbandry, veterinary, and medical clinical practice, the prevalence of AMR and the important responsible genes as a risk factor for human and animal health should be investigated.

The species Escherichia coli (Enterobacteriaceae; E. coli) are part of the normal intestinal flora in humans and animals but often lead to urinary and gastrointestinal tract infection, hemolytic-uremic syndrome (HUS), sepsis, surgical site infection and meningitis. There is a lot of information in the literature, but in general, currently, over 171 somatic $(\mathrm{O}), 55$ flagellar $(\mathrm{H})$, and 80 capsular $(\mathrm{K})$ antigens and 160 serological strains are known [10]. The most pathogenic E. coli strains are divided into several groups: enterohemorrhagic (EHEC), enterotoxigenic (ETEC), enteropathogenic (EPEC), Shiga toxin (verotoxin)-producing (STEC/VTEC), avian pathogenic (APEC), etc. Newborn and weaned animals are particularly susceptible to enteric colibacillosis, which involve ETEC and EPEC [11] due to their genetic immunodeficiency at birth [12]. The ETEC strains, which cause post-weaning diarrhea, produce heat-stable toxins a and b (STa and STb, respectively), which induce water and electrolyte loss from the intestine, and/or heat-labile enterotoxins (LT) $[13,14]$. The mechanism of action of STa and STb in newborns whith colibacillosis has been studied. STa stimulates the cyclic guanosine monophosphate (cGMP) production in the intestinal epithelial cells, which leads to electrolyte eand fluid secretion [15]. $\mathrm{STb}$ induces the duodenal and jejunal secretion of water and electrolytes by an uptake of $\mathrm{Ca}^{2+}$, leading to intoxication by $\mathrm{Na}^{+}$and $\mathrm{Cl}^{-}$accumulation and stimulates bicarbonate $\left(\mathrm{HCO}^{3-}\right)$ secretion in cells. LT promotes the adherence, activates adenylyl cyclase in the basolateral plasma membrane of intestinal epithelial cells and leads to hypersecretion of electrolytes and water causing dehydration [16]. The fimbriae F4 occurs in both newborn and weaned animals with diarrhea [11]. The F4 ETEC strains colonize the length of jejunum and ileum [15]. The diarrhea caused by ETEC is usually watery with a characteristic yellowish, grey, or slightly pink color and smell [11]. The EPEC strains possess intimin Eae (outer membrane protein), which is responsible for the bacterial attachment to the host intestinal epithelium, which together with a complex secretion system (type III) leads to lesion formation [17]. The STEC/VPEC and certain EHEC strains produce different Shiga toxins (also called verotoxins), such as Stx1 (VT1), Stx2 (VT2), and caused hemorrhagic colitis in animals, and HUS in humans by contact [18]. There was an increasing trend in 2014-2018 of STEC human infections, which were the third most commonly reported zoonosis in the EU [19]. The EARS-NET reported the weighted mean percentages for third-generation cephalosporin resistance and aminoglycoside resistance in the population, as well as for combined resistance to three key antimicrobial groups (fluoroquinolones, third-generation cephalosporins, and aminoglycosides) [20].

Unfortunately, the data for Bulgaria are too scarce, as timely and constant monitoring is not applied in the areas around swine farms by responsible organizations. In addition, no systematic study has been conducted in Bulgaria on the prevalence of $E$. coli, their resistance to antibiotics, the prevalence of GAR in them, and biofilm formation capacity until now. The results will contribute to solving a global problem caused by the uncontrolled treatment of animals with antibiotics. Therefore, for the first time, our team investigated the path of distribution of the food-borne pathogenes E. coli and their GAR from faeces and lagoons.

\section{Results}

\subsection{Isolation of Single Bacterial Cultures}

We isolated a total of 28 single colonies (15 with 3 lagoons and 13 with 3 faeces on CHROMagar CCA). This media detected and enumerated $\beta$-glucuronidase-positive $E$. coli (metallic blue to violet) and other coliforms (pink to red), according to ISO 9308-1. From them, 17 colonies were suspected for E. coli, and 11 colonies were suspected for coliforms. 
In the present study, we used only colonies, which were suspected for E. coli for subsequent experiments (Figure 1).

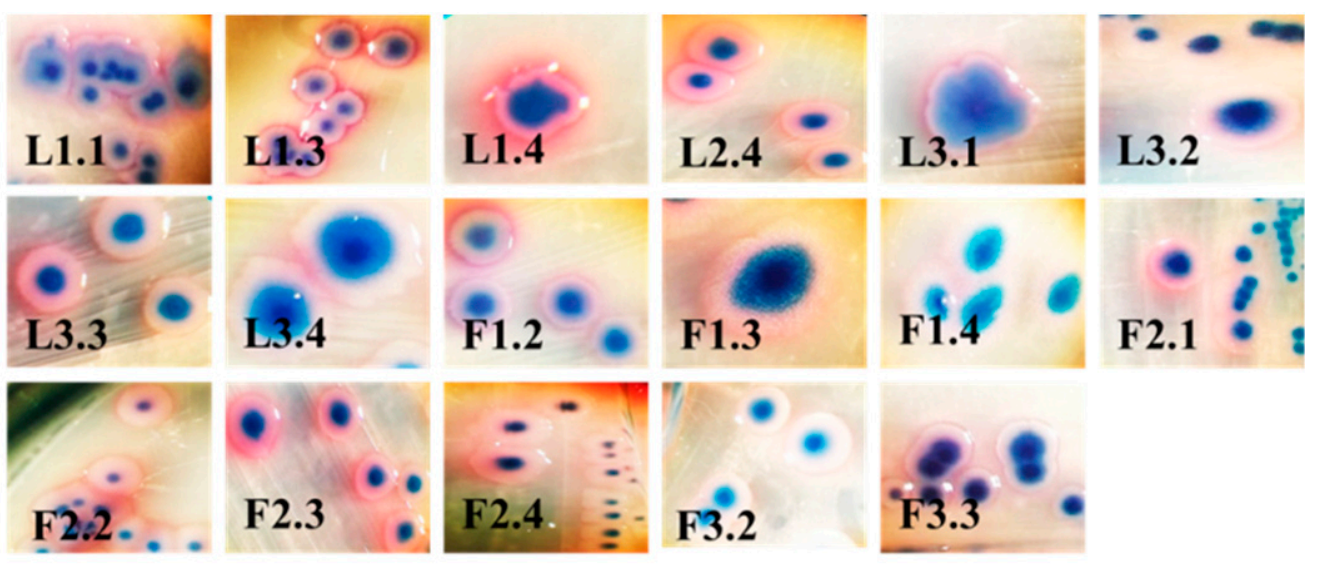

Figure 1. Morphological characteristics of bacterial strains, which were suspected for Escherichia coli (E. coli). Legend: L, lagoon; F, faeces; the first number, the number of probe; the second number, the number of isolate.

\subsection{Biochemical and $16 S$ rDNA Characterization}

All 17 suspected for $E$. coli colonies were positive for indole and were confirmed after biochemical identification by BD Phoenix M50. In addition, 16S rDNA E. coli characterization by PCR (Figure 2) was carried out. We detected E. coli in both total $16 \mathrm{~S}$ rDNAs from faeces and lagoons (Figure 2A) and from single colonies (Figure 2B,C).
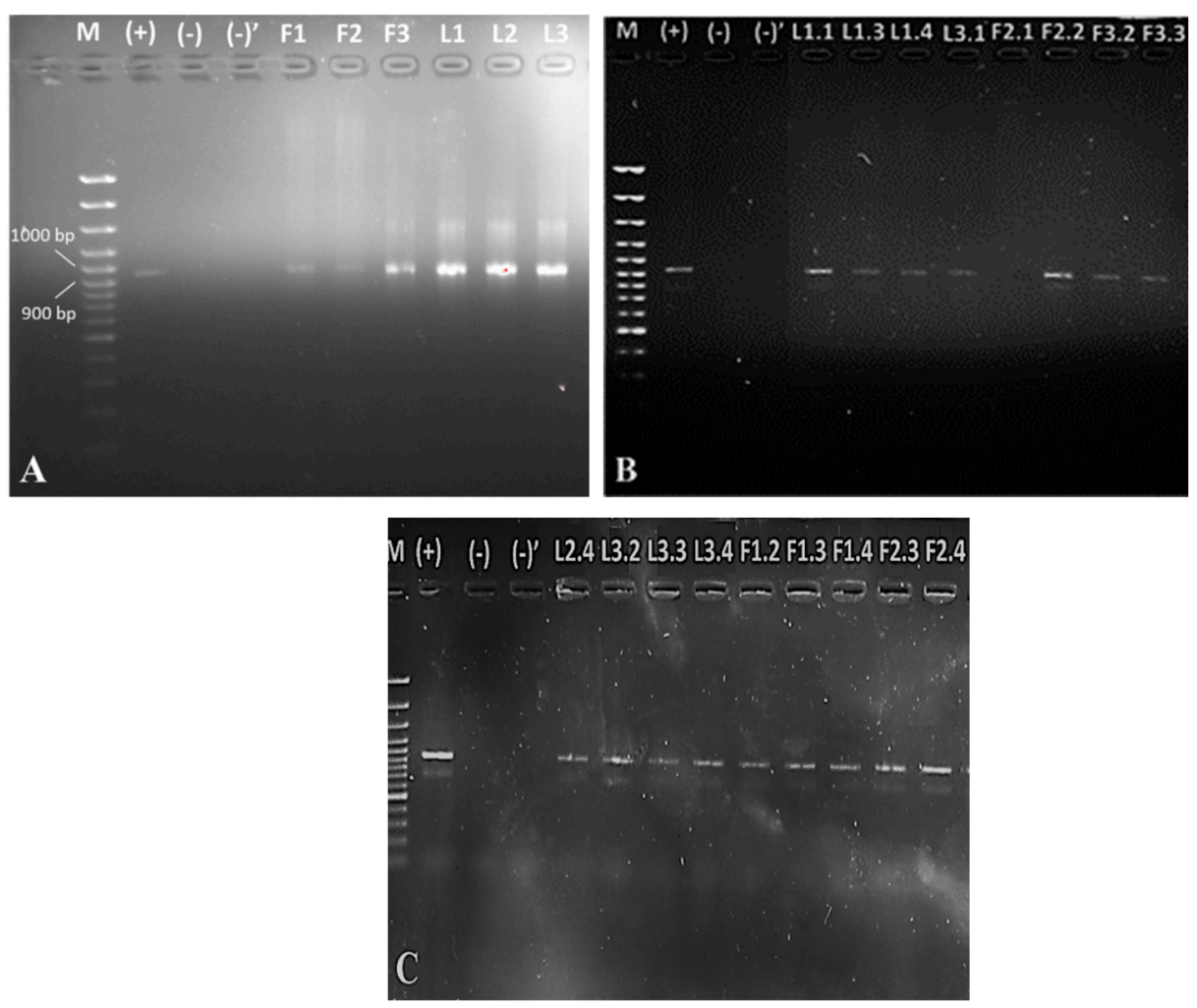

Figure 2. Detection of E. coli isolated from lagoons L1-L3 and faeces F1-F3 (A) and from single colonies $(\mathrm{B}, \mathrm{C})$ by $16 \mathrm{~S}$ rDNA PCR. Legend: M, marker; $(+)$, positive control (E. coli O:157 for 16S rRNA PCR identification); $(-)$, control of purity in the place of dispensing MasterMix; $(-)^{\prime}$, control of purity in the place of dispensing DNA. 
Interestingly, isolate F2.1 was negative for E. coli by $16 \mathrm{~S}$ rDNA detection. Therefore, our studies continued the study on other bacterial strains with proven genetic information.

\subsection{Test for Biofilm Formation}

We investigated the possibility of biofilm formation of all confirmed strains.

From all the tested 16 isolates $(100 \%), 5$ strains formed strong biofilms $(31.25 \%), 6$ strains formed moderate biofilms (37.5\%), 4 strains formed weak biofilms $(25 \%)$, and 1 strain did not form a biofilm (6.25\%).

\subsection{Antibiotic Resistance}

According to the results obtained from BD Phoenix M50 (Table 2), 11 of the total 16 isolates were resistant to ampicillin (68.75\%), trimethoprim $(31.25 \%)$, and even the combination between trimethoprim and sulfamethoxazole (18.75\%). Only one of them (L1.3; 6.25\%) was also resistant to gentamicin, amoxicillin/clavulanic acid, ciprofloxacin, and colistin. Interestingly, this strain formed a strong biofilm (Table 1).

Table 1. Adherence of the isolated E. coli from lagoons and faeces, compared with those of the controls.

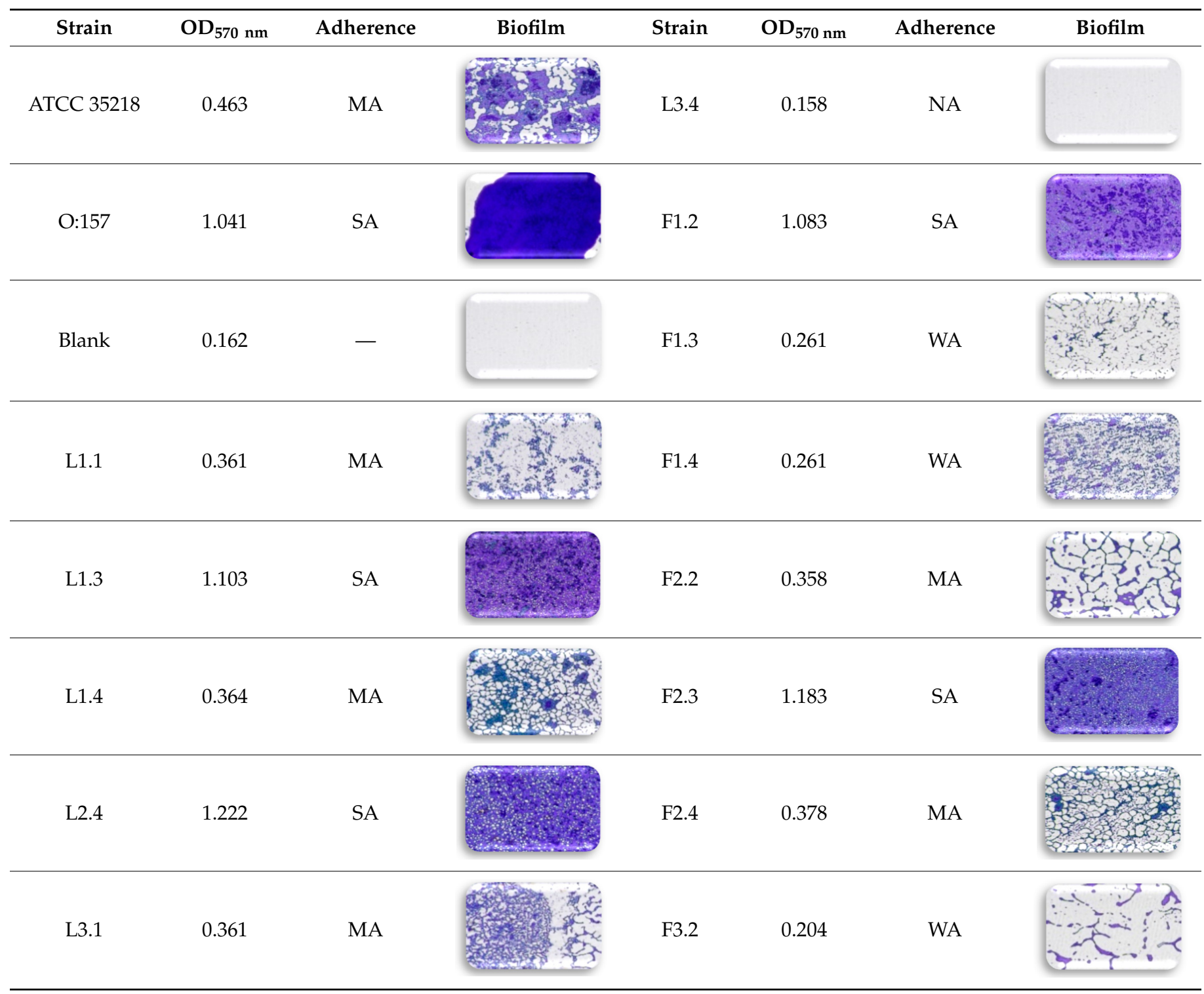


Table 1. Cont.

\begin{tabular}{|c|c|c|c|c|c|c|c|}
\hline Strain & $\mathrm{OD}_{570 \mathrm{~nm}}$ & Adherence & Biofilm & Strain & $\mathrm{OD}_{570 \mathrm{~nm}}$ & Adherence & Biofilm \\
\hline L3.2 & 0.382 & MA & & F3.3 & 0.328 & WA & \\
\hline L3.3 & 1.188 & SA & & & & & \\
\hline
\end{tabular}

Legend: NA, non-adherent confirmed E. coli strains; WA, weakly adherent confirmed E. coli strains; MA, moderately adherent confirmed $E$. coli strains; SA, strongly adherent confirmed E. coli strains.

In addition, we performed an antibiotic disc diffusion test (Table 3). We found the resistances to amoxicillin (75\%), tetracycline and chloramphenicol $(56.25 \%)$, trimethoprim/sulfamethoxazole (43.75\%), doxycycline hydrochloride (37.5\%), and nalidixic acid $(25 \%)$ in all the 16 isolates. The results for the resistance to ampicillin $(68.75 \%)$ from BD Phoenix M50 were confirmed. Strain L1.3 was resistant also to pefloxacin. The resistances of two lagoon isolates (L1.4 and L3.4) to streptomycin were found. Isolate L1.4 formed a moderate biofilm, while isolate L3. did not (Table 1).

\subsection{Detection of Antibiotic Resistance Genes}

From a total of 12 tested strains resistant to $\beta$-lactam antibiotic, only L1.3 carried blaTEM and blaSHV $\beta$-lactam-resistance genes. The presence of $\operatorname{amp} \mathrm{C} \beta$-lactamases gene in three isolates from pigs for fattening and in four isolates from lagoons was found (Figure 3).

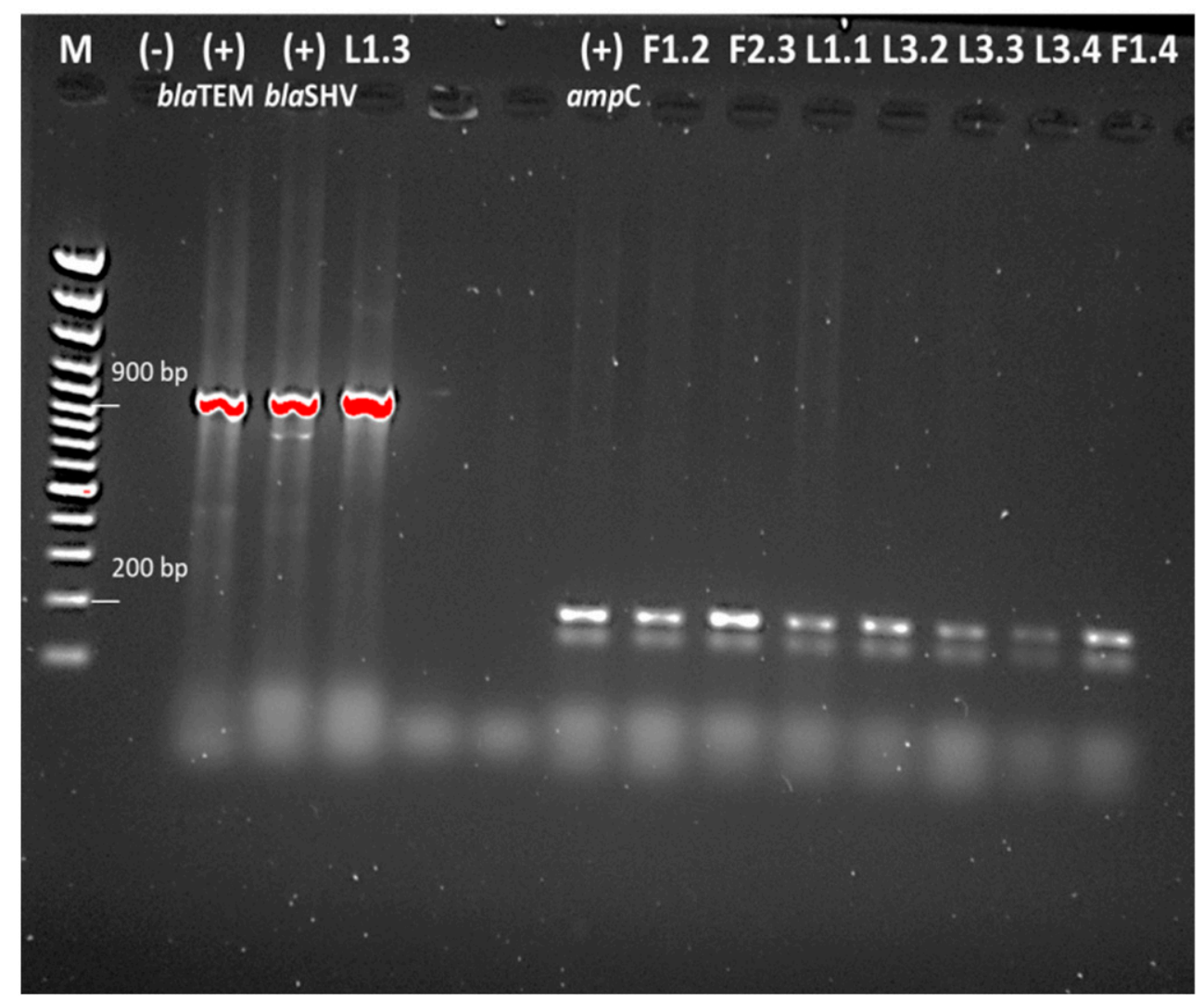

Figure 3. Detection of $\operatorname{ampC} \beta$-lactamases gene and blaTEM and blaSHV $\beta$-lactam-resistance genes. 


\section{Discussion}

The resistance in E. coli to some of the most widely used antibiotics in medical practice for the treatment of urinary tract infections, such as fluoroquinolones and sulfonamides, is a global problem. Due to the rapid spread of GAR, the treatment of urinary tract infections is ineffective in more than $50 \%$ of patients. According to a World Health Organization (WHO) report in 2017, most European Antimicrobial Resistance Surveillance Network (EARS-Net) countries have resistance between $10 \%$ and $25 \%$, while more than $25 \%$ are found in Bulgaria, Cyprus, Italy, and Slovakia. Among Central Asian and European Surveillance of Antimicrobial Resistance (CAESAR) countries, the reported resistance exceeds 50\% (Montenegro, Russia, Northern Macedonia, and Turkey), while in Serbia it varies between $25 \%$ and $50 \%$ [21]. The EARS-Net data show statistically significant increase in resistance of $E$. coli isolates in the EU to third generation cephalosporins [22]. The emergence of carbapenem-resistant $E$. coli has recently been identified, which is a serious challenge. Although the proportions of resistance are still low in Europe (around $1 \%$ and more), there is a tendency to increase worldwide [21,22]. A major mechanism of cephalosporin resistance is the production of $\beta$-lactamases, which hydrolyzes the $\beta$-lactam ring and inactivates $\beta$-lactam chemotherapeutics. The genetic determinants of resistance demonstrated in $E$. coli isolates include extended-spectrum $\beta$-lactamases (ESBL) encoded by various plasmid genes (blaSHV, blaCMY-2, blaTEM, etc.), as well as a number of GARs for quinolone resistance ( $q n r)$, trimethoprim ( $h h f)$, aminoglycosides (aac(3)), etc. [23].

Studies in Bulgaria showed that resident strains of E. coli have a clear phenotypic and genotypic resistance profile to chemotherapeutics used in animal husbandry and human medicine. A high percent of resistance among pathogenic E. coli strains isolated from pigs in 2010-2015 was observed, which is a very alarming fact. In comparison with a previous study conducted in 2000-2004, the resistances to tetracycline antibiotics, streptomycin, spectinomycin, ampicillin, and sulfonamides, have increased by twofold. The percentage of resistance strains to ciprofloxacin has increased by tenfold during the same period. The widespread distribution of resistant $E$. coli strains has also been demonstrated in isolates, representative of the resident intestinal microflora of healthy pigs. The results showed the prevalence of aad $\mathrm{A} 1$ genes for determining streptomycin/spectinomycin resistance, tet(A) for determining tetracycline resistance, and strA/strB for determining streptomycin resistance. There is a limit information about the presence of the genes sul 1 and sul2, blaTEM, and tet(B), which determine the bacterial resistances to sulfamethoxazole, aminopenicillins and cephalosporins of first generation, tetracyclines, respectively and the intl gene, which is responsible for the synthesis of the integrase enzyme from class 1 integrons. The lowest distribution is for the aac 2 gene, which is responsible for the resistance to gentamicin, kanamycin, tobramycin and netilmicin [24]. These facts support the hypothesis that the horizontal transfer of GAR in MDR commensal gut bacteria is one of the important risk factors for gene transfer, mainly through foodstuffs of animal origin or from the environment to humans.

Fluoroquinolone-resistant E. coli in China and Korea have been isolated from fecal samples [25,26]. From 171 samples isolated in 2015, from which $52(30.4 \%)$ were from diseased swine and the other $119(69.6 \%)$ were from healthy swine, a total of $59 \mathrm{E}$. coli isolates $(34.5 \%)$ were confirmed as fluoroquinolone-resistant $21(40.4 \%$ from diseased swine) and 38 (31.9\% from healthy swine)). The researchers found plasmid-mediated quinolone-resistance (PMQR) genes in 9 isolates (15.3\%) and efflux pump activity in 56 isolates $(94.9 \%)$. The authors reported that the resistance to fluoroquinolones has increased significantly in swine compared to in previous studies in Korea, although fluoroquinolones have been banned as a feed additive since 2009. These authors investigated the qnr A and $q n r \mathrm{~B}$ genes, but as in our study, they did not prove them [25]. All isolates from China showed the moderate rates of the resistance to norfloxacin (43.0\%), ciprofloxacin (47.6\%), ofloxacin (47.0\%), and levofloxacin (38.8\%). They also did not detect the presence of $q n r \mathrm{~A}$ and qnrB genes [26]. Hu et al. (2017) suggested that the predominant PMQR genes detected in human isolates were $q n r \mathrm{~A}$ and $q \eta r \mathrm{~B}$, whereas $q \eta r \mathrm{~S}$ was detected in swine samples. 
Probably for this reason, we also failed to confirm any of these two genes ( $q n r \mathrm{~A}$ and $q n r \mathrm{~B})$ (Figure 3).

According to a study by the National Diagnostic Research Veterinary Medical Institute (NDRVMI) and University of Forestry in Bulgaria conducted in the period 2012-2014, the number of positive strains of $E$. coli from all samples isolated from different pig farms in the country ranged between $50 \%$ and $70 \%$. Above $75 \%$ of them were resistant to amoxicillin and erythromycin and from $51 \%$ to $75 \%$ of them were resistant to ampicillin, oxytetracycline, thiamulin, streptomycin, doxycycline, tylosin, and tilmicosin. It has been found that sensitivity is most strongly established to non-use agents (amikacin, cefquin, and cefotaxime), less commonly used in practice (kanamycin), or new agents in the fluorinated quinolone groups (ciprofloxacin, enrofloxacin, and pefloxacin) and amphenicols [27].

We performed antimicrobial susceptibility tests against additional eight classes of drugs and six other antibiotics (a total of 34 antimicrobial agents). From all isolated E. coli strains, $87.5 \%$ of them are MDR (only F1.4 and L3.1 were sensitive to the antibiotics used). Only $18.75 \%$ of all isolated E. coli strains were resistant to aminoglycosides (L1.4 and L3.4 were resistant to streptomycin, and L1.3 was resistant to gentamicin), $81.25 \%$ of them were resistant to penicillins, $25 \%$ of them were resistant to fluoroquinolones, $6.25 \%$ of them (only L3.2) were resistant to macrolides, and $68.75 \%$ of them were resistant to other antibiotics. The isolated E. coli strains from swine faeces and lagoons were susceptible to monobactams, cephalosporins, and carbapenems. We found high resistance to $\beta$-lactam (amoxicillin and ampicillin) and tetracycline (tetracycline and doxycycline hydrochloride) antibiotics (Tables 2 and 3). The percentage of resistance was also high. Moreover, compared with a previous study in Bulgaria, the current research demonstrates a substantial increase in resistance to trimethoprim/sulfamethoxazole from 7.1\% in the period 2012-2014 [27] to $43.75 \%$ in our study and a significant increase in resistance to nalidix acid from $11.1 \%$ in the period 2012-2014 [27] to 25\% that we found. The ampicillin and amoxicillin resistance are found today (70-80\%), including those to gentamicin and pefloxacin (about 4-7\%) [27]. Decreased resistances to doxycycline (from 64.7\% in the period 2012-2014 [27] to 37.5\% in our case), streptomycin (from $63.1 \%$ in the period 2012-2014 [27] to $12.5 \%$ found by us), erythromycin (from $80 \%$ in the period 2012-2014 [27] to 6.25\%) have been observed. Dimitrova et al. (2016) also documented that the isolated E. coli strains were susceptible to amikacin, cefotaxim, ciprofloxacin and norfloxacin [27]. Urumova (2016) studied the AMR in E. coli in the period 2012-2016 from different regions in Bulgaria (Shumen, Ruse, Razgrad, Yambol, and Varna). She found high resistance in growing pigs, compared with that in suckling pigs, fattening swine, and lagoons [24]. Compared with her study, it was found that the resistances to ampicillin (68.75\%) and amoxicillin/clavulanic acid (from $2.2 \%$ in the period 2012-2016 to $6.25 \%$ in our study) were doubled and tripled, respectively [24]. The researcher also proved high resistance to streptomycin (69.4\%) [24], as reported by previous authors [27]. A slight resistance to ciprofloxacin (5.2\%) was observed, which was also confirmed by our results (6.25\%). The resistance to tetracycline was almost not changed from $73.3 \%$ in the period 2012-2016 [24] to $56.25 \%$ found by us, indicating that the antibiotic continues to be used in swine farms. Only one isolate out of a total of 157 growing animals was found was to be resistant to ceftazidime and cefotaxime [24]. 
Table 2. Antibiotic resistances of the isolates identified as E. coli by BD Phoenix M50.

\begin{tabular}{|c|c|c|c|c|c|c|c|c|c|c|c|c|c|c|c|c|c|c|c|}
\hline Drug Class & Antibiotic/Strain & F1.2 & F1.3 & F1.4 & F2.1 & F2.2 & F2.3 & F2.4 & F3.2 & F3.3 & L1.1 & L1.3 & L1.4 & L2.4 & L3.1 & L3.2 & L3.3 & L3.4 & $\begin{array}{l}\text { E. coli } \\
\text { ATCC } \\
35218\end{array}$ \\
\hline \multirow{2}{*}{ Aminoglycosides } & Tobramycin & $\mathrm{S}$ & $\mathrm{S}$ & $\mathrm{S}$ & $\mathrm{S}$ & $\mathrm{S}$ & $\mathrm{S}$ & $\mathrm{S}$ & $\mathrm{S}$ & $\mathrm{S}$ & $\mathrm{S}$ & $\mathrm{S}$ & $\mathrm{S}$ & $\mathrm{S}$ & $\mathrm{S}$ & $\mathrm{S}$ & $\mathrm{S}$ & $\mathrm{S}$ & $\mathrm{S}$ \\
\hline & Gentamicin & $\mathrm{S}$ & $\mathrm{S}$ & $\mathrm{S}$ & $\mathrm{S}$ & $\mathrm{S}$ & $\mathrm{S}$ & $\mathrm{S}$ & $\mathrm{S}$ & $\mathrm{S}$ & $\mathrm{S}$ & $\mathbf{R}$ & $\mathrm{S}$ & $\mathrm{S}$ & $\mathrm{S}$ & $\mathrm{S}$ & $\mathrm{S}$ & $\mathrm{S}$ & $\mathrm{S}$ \\
\hline \multirow[b]{2}{*}{ Penicillins } & Amoxicillin/clavulanic acid & $\mathrm{S}$ & $\mathrm{S}$ & $\mathrm{S}$ & $\mathrm{S}$ & $\mathrm{S}$ & $\mathrm{S}$ & $\mathrm{S}$ & $\mathrm{S}$ & $\mathrm{S}$ & $\mathrm{S}$ & $\mathbf{R}$ & $\mathrm{S}$ & $\mathrm{S}$ & $\mathrm{S}$ & $\mathrm{S}$ & $\mathrm{S}$ & $\mathrm{S}$ & $\mathrm{S}$ \\
\hline & Ampicillin & $\mathrm{S}$ & $\mathbf{R}$ & $\mathbf{R}$ & $\mathrm{S}$ & $\mathrm{S}$ & $\mathbf{R}$ & $\mathrm{S}$ & $\mathbf{R}$ & $\mathbf{R}$ & $\mathbf{R}$ & $\mathbf{R}$ & $\mathrm{S}$ & $\mathbf{R}$ & $\mathrm{S}$ & $\mathbf{R}$ & $\mathbf{R}$ & $\mathbf{R}$ & $\mathbf{R}$ \\
\hline Monobactams & Aztreonam & $\mathrm{S}$ & $\mathrm{S}$ & $\mathrm{S}$ & $\mathrm{S}$ & $\mathrm{S}$ & $\mathrm{S}$ & $\mathrm{S}$ & $\mathrm{S}$ & $\mathrm{S}$ & $\mathrm{S}$ & $\mathrm{S}$ & $\mathrm{S}$ & $\mathrm{S}$ & $\mathrm{S}$ & $\mathrm{S}$ & $\mathrm{S}$ & $\mathrm{S}$ & $\mathrm{S}$ \\
\hline \multirow{5}{*}{ Cephalosporins } & Cefazolin & I & $\mathbf{I}$ & $\mathbf{I}$ & $\mathbf{I}$ & $x$ & $\mathbf{I}$ & $\mathbf{I}$ & $\mathbf{I}$ & $\mathbf{I}$ & $\mathbf{I}$ & $\mathbf{I}$ & $\mathbf{I}$ & $\mathbf{I}$ & $\mathbf{I}$ & $\mathbf{I}$ & I & I & $\mathbf{I}$ \\
\hline & Cefotaxime & $\mathrm{S}$ & $\mathrm{S}$ & $\mathrm{S}$ & $\mathrm{S}$ & $\mathrm{S}$ & $\mathrm{S}$ & $\mathrm{S}$ & $\mathrm{S}$ & $\mathrm{S}$ & $\mathrm{S}$ & $\mathrm{S}$ & $\mathrm{S}$ & $\mathrm{S}$ & $\mathrm{S}$ & $\mathrm{S}$ & $\mathrm{S}$ & $\mathrm{S}$ & $\mathrm{S}$ \\
\hline & Ceftazidime & $\mathrm{S}$ & $\mathrm{S}$ & $\mathrm{S}$ & $\mathrm{S}$ & $\mathrm{S}$ & $\mathrm{S}$ & $\mathrm{S}$ & $\mathrm{S}$ & $\mathrm{S}$ & $\mathrm{S}$ & $\mathrm{S}$ & $\mathrm{S}$ & $\mathrm{S}$ & $\mathrm{S}$ & $\mathrm{S}$ & $\mathrm{S}$ & $\mathrm{S}$ & $\mathrm{S}$ \\
\hline & Cefuroxime & 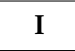 & I & I & $\mathbf{I}$ & I & I & I & I & I & I & I & I & I & I & $\mathbf{I}$ & $\mathrm{I}$ & $\mathrm{I}$ & I \\
\hline & Cephalexin & $\mathrm{S}$ & $\mathrm{S}$ & $S$ & $S$ & $\mathrm{~S}$ & $S$ & $\mathrm{~S}$ & $\mathrm{~S}$ & $S$ & $\mathrm{~S}$ & $S$ & $S$ & $S$ & $S$ & $S$ & $\mathrm{~S}$ & $\mathrm{~S}$ & $\mathrm{~S}$ \\
\hline Fluoroquinolones & Ciprofloxacin & $\mathrm{S}$ & $\mathrm{S}$ & $\mathrm{S}$ & $S$ & I & $\mathrm{S}$ & $\mathrm{S}$ & $\mathrm{S}$ & $\mathrm{S}$ & $\mathrm{S}$ & $\mathbf{R}$ & $\mathrm{S}$ & $\mathrm{S}$ & $\mathrm{S}$ & $\mathrm{S}$ & $\mathrm{S}$ & $\mathrm{S}$ & $\mathrm{S}$ \\
\hline \multirow[t]{2}{*}{ Carbapenems } & Imipenem & $\mathrm{S}$ & $\mathrm{S}$ & $\mathrm{S}$ & $\mathrm{S}$ & $\mathrm{S}$ & $\mathrm{S}$ & $\mathrm{S}$ & $\mathrm{S}$ & S & $\mathrm{S}$ & $\mathrm{S}$ & $\mathrm{S}$ & S & $\mathrm{S}$ & $\mathrm{S}$ & $\mathrm{S}$ & $\mathrm{S}$ & $\mathrm{S}$ \\
\hline & Meropenem & $\mathrm{S}$ & $\mathrm{S}$ & $\mathrm{S}$ & $\mathrm{S}$ & $\mathrm{S}$ & $\mathrm{S}$ & $\mathrm{S}$ & $\mathrm{S}$ & $\mathrm{S}$ & $\mathrm{S}$ & $\mathrm{S}$ & $\mathrm{S}$ & $\mathrm{S}$ & $\mathrm{S}$ & $\mathrm{S}$ & $\mathrm{S}$ & $\mathrm{S}$ & $\mathrm{S}$ \\
\hline \multirow{5}{*}{ Other agents } & Colistin & $x$ & $x$ & $x$ & $x$ & $x$ & $x$ & $x$ & $x$ & $x$ & $x$ & $\mathbf{R}$ & $x$ & $x$ & $x$ & $x$ & $x$ & $x$ & $x$ \\
\hline & Fosfomycin & $\mathrm{S}$ & $\mathrm{S}$ & $\mathrm{S}$ & $\mathrm{S}$ & $\mathrm{S}$ & $\mathrm{S}$ & $\mathrm{S}$ & $\mathrm{S}$ & $\mathrm{S}$ & $\mathrm{S}$ & $\mathrm{S}$ & $\mathrm{S}$ & $\mathrm{S}$ & $\mathrm{S}$ & $\mathrm{S}$ & $\mathrm{S}$ & $\mathrm{S}$ & $\mathrm{S}$ \\
\hline & Nitrofurantoin & $\mathrm{S}$ & $\mathrm{S}$ & $\mathrm{S}$ & $\mathrm{S}$ & $\mathrm{S}$ & $\mathrm{S}$ & $\mathrm{S}$ & $\mathrm{S}$ & $\mathrm{S}$ & $\mathrm{S}$ & $\mathrm{S}$ & $\mathrm{S}$ & $\mathrm{S}$ & $\mathrm{S}$ & $\mathrm{S}$ & $\mathrm{S}$ & $\mathrm{S}$ & $\mathrm{S}$ \\
\hline & Trimethoprim & $\mathbf{R}$ & $\mathrm{S}$ & $\mathrm{S}$ & $\mathrm{S}$ & $\mathbf{R}$ & $\mathrm{S}$ & $\mathrm{S}$ & $\mathbf{R}$ & $\mathbf{R}$ & $\mathrm{S}$ & $\mathbf{R}$ & $\mathrm{S}$ & $\mathrm{S}$ & $\mathrm{S}$ & $\mathrm{S}$ & $\mathrm{S}$ & $\mathrm{S}$ & $\mathrm{S}$ \\
\hline & Trimethoprim/sulfamethoxazole & $\mathbf{R}$ & $\mathrm{S}$ & $\mathrm{S}$ & $\mathrm{S}$ & $\mathbf{R}$ & $\mathrm{S}$ & S & $\mathrm{S}$ & $\mathrm{S}$ & $\mathrm{S}$ & $\mathbf{R}$ & $\mathrm{S}$ & $\mathrm{S}$ & $\mathrm{S}$ & $\mathrm{S}$ & $\mathrm{S}$ & $\mathrm{S}$ & $\mathrm{S}$ \\
\hline
\end{tabular}


Table 3. Antibiotic resistances by the disc diffusion method of the isolated E. coli strains.

\begin{tabular}{|c|c|c|c|c|c|c|c|c|c|c|c|c|c|c|c|c|c|c|c|}
\hline Drug Class & Antibiotic/Strain & F1.2 & F1.3 & F1.4 & F2.2 & F2.3 & F2.4 & F3.2 & F3.3 & L1.1 & L1.3 & L1.4 & L2.4 & L3.1 & L3.2 & L3.3 & L3.4 & $\begin{array}{l}\text { E. coli } \\
\text { O:157 }\end{array}$ & $\begin{array}{l}\text { E. coli } \\
\text { ATCC } \\
35218\end{array}$ \\
\hline Tetracycline & Tetracycline & $\mathbf{R}$ & $S$ & $\mathrm{~S}$ & $\mathbf{R}$ & I & $\mathrm{S}$ & $\mathbf{R}$ & $\mathrm{S}$ & $\mathbf{R}$ & $\mathbf{R}$ & $\mathbf{R}$ & $\mathbf{R}$ & I & $\mathbf{R}$ & $\mathbf{R}$ & I & $\mathbf{R}$ & $\mathrm{S}$ \\
\hline \multirow{2}{*}{ Macrolides } & Erythromycin & $\mathrm{S}$ & I & $\mathrm{S}$ & $\mathbf{I}$ & $\mathrm{S}$ & $\mathrm{S}$ & I & $\mathbf{I}$ & $\mathbf{I}$ & $\mathbf{I}$ & $\mathbf{I}$ & $S$ & I & $\mathbf{R}$ & $\mathrm{S}$ & $\mathrm{S}$ & $\mathrm{S}$ & $\mathrm{S}$ \\
\hline & Clarithromycin & $S$ & I & $S$ & $S$ & $S$ & $S$ & I & $\mathrm{S}$ & $\mathrm{S}$ & $S$ & $\mathrm{~S}$ & $S$ & $\mathrm{~S}$ & $\mathrm{~S}$ & $\mathrm{~S}$ & $\mathrm{~S}$ & $\mathrm{~S}$ & $\mathrm{~S}$ \\
\hline Cephalosporins & Cefamandole & $S$ & $S$ & $S$ & $\mathrm{~S}$ & $S$ & $S$ & $\mathrm{~S}$ & $\mathrm{~S}$ & $\mathrm{~S}$ & $\mathrm{~S}$ & $S$ & $S$ & $\mathrm{~S}$ & $S$ & $S$ & $\mathrm{~S}$ & $\mathrm{~S}$ & $S$ \\
\hline \multirow[t]{2}{*}{ Fluoroquinolones } & Pefloxacin & $S$ & $S$ & $S$ & $S$ & $\mathrm{~S}$ & $S$ & $S$ & $\mathrm{~S}$ & $\mathrm{~S}$ & $\mathbf{R}$ & $S$ & $\mathrm{~S}$ & $S$ & $S$ & $S$ & $\mathrm{~S}$ & $S$ & $\mathrm{~S}$ \\
\hline & Ciprofloxacin & $S$ & $\mathrm{~S}$ & $S$ & $\mathrm{~S}$ & $\mathrm{~S}$ & $S$ & $\mathrm{~S}$ & $\mathrm{~S}$ & $\mathrm{~S}$ & $\mathrm{~S}$ & $\mathrm{~S}$ & $\mathrm{~S}$ & $\mathrm{~S}$ & $\mathrm{~S}$ & $\mathrm{~S}$ & $\mathrm{~S}$ & $\mathrm{~S}$ & $\mathrm{~S}$ \\
\hline \multirow{5}{*}{ Penicillins } & Ampicillin & $\mathbf{R}$ & $\mathbf{R}$ & $\mathrm{S}$ & $S$ & $\mathbf{R}$ & $\mathrm{S}$ & $\mathbf{R}$ & $\mathbf{R}$ & $\mathbf{R}$ & $\mathbf{R}$ & $\mathrm{S}$ & $\mathbf{R}$ & $S$ & $\mathbf{R}$ & $\mathbf{R}$ & $\mathbf{R}$ & $\mathrm{S}$ & $\mathbf{R}$ \\
\hline & Amoxicillin & $S$ & $\mathbf{R}$ & $\mathbf{R}$ & $\mathrm{S}$ & $\mathbf{R}$ & $S$ & $\mathbf{R}$ & $\mathbf{R}$ & $\mathbf{R}$ & $\mathbf{R}$ & $\mathbf{R}$ & $\mathbf{R}$ & $\mathrm{S}$ & $\mathbf{R}$ & $\mathbf{R}$ & $\mathbf{R}$ & n.m. & $\mathbf{R}$ \\
\hline & Amoxicillin/clavulanic acid & $\mathrm{S}$ & $\mathrm{S}$ & $\mathrm{S}$ & $\mathrm{S}$ & $\mathrm{S}$ & $\mathrm{S}$ & $\mathrm{S}$ & $\mathrm{S}$ & $\mathrm{S}$ & $\mathrm{S}$ & $\mathrm{S}$ & $\mathrm{S}$ & $S$ & $\mathrm{~S}$ & $\mathrm{~S}$ & $\mathrm{~S}$ & $\mathrm{~S}$ & $\mathrm{~S}$ \\
\hline & Penicillin & $\mathrm{S}$ & $S$ & $\mathrm{~S}$ & $\mathrm{~S}$ & $\mathrm{~S}$ & $\mathrm{~S}$ & $\mathrm{~S}$ & $\mathrm{~S}$ & $\mathrm{~S}$ & $\mathrm{~S}$ & $\mathrm{~S}$ & $\mathrm{~S}$ & $\mathrm{~S}$ & $\mathrm{~S}$ & $\mathrm{~S}$ & $\mathrm{~S}$ & $\mathrm{~S}$ & $\mathrm{~S}$ \\
\hline & Carbenicillin & $S$ & $S$ & $S$ & $\mathrm{~S}$ & $S$ & $S$ & $\mathrm{~S}$ & $\mathrm{~S}$ & $\mathbf{I}$ & $\mathbf{I}$ & $\mathrm{S}$ & $\mathrm{S}$ & $\mathbf{I}$ & $\mathrm{S}$ & $S$ & $\mathrm{~S}$ & $S$ & $\mathrm{~S}$ \\
\hline Aminoglycosides & Streptomycin & $S$ & $S$ & $S$ & $\mathrm{~S}$ & $S$ & $S$ & $\mathrm{~S}$ & $\mathrm{~S}$ & $\mathrm{~S}$ & $\mathbf{I}$ & $\mathbf{R}$ & $\mathrm{S}$ & $S$ & $\mathrm{~S}$ & $\mathrm{~S}$ & $\mathbf{R}$ & $\mathrm{S}$ & $\mathbf{R}$ \\
\hline \multirow{2}{*}{ Other agents } & Chloramphenicol & $\mathbf{R}$ & $\mathbf{R}$ & $S$ & $\mathbf{R}$ & $\mathbf{R}$ & $\mathrm{S}$ & $\mathbf{R}$ & $\mathbf{R}$ & $\mathrm{S}$ & $\mathrm{S}$ & $\mathrm{S}$ & $\mathbf{R}$ & $\mathrm{S}$ & $\mathrm{S}$ & $\mathbf{R}$ & $\mathbf{R}$ & $\mathbf{R}$ & $\mathbf{R}$ \\
\hline & Trimethoprim/sulfamethoxazole & $\mathbf{R}$ & $\mathbf{R}$ & $\mathrm{S}$ & $\mathbf{R}$ & $\mathrm{S}$ & $\mathrm{S}$ & $\mathbf{R}$ & $\mathbf{R}$ & $\mathrm{S}$ & $\mathbf{R}$ & $\mathbf{R}$ & $\mathrm{S}$ & $\mathrm{S}$ & $\mathrm{S}$ & $\mathrm{S}$ & $\mathrm{S}$ & $\mathrm{S}$ & $\mathrm{S}$ \\
\hline
\end{tabular}




\section{Materials and Methods}

\subsection{Swine Farm and Sample Collection}

The study included a swine farm near Kostinbrod, which was founded in 2008 and today is a part of the Hog and Pig Farming Companies in Bulgaria. It was designed for up to 8200 breeding animals and their offspring. It was built on an area of about 70.5 decares with introduced biosecurity measures. All normative documents for protection and animal welfare were observed. Three samples from pig faeces (F1-F3) and three samples from lagoons (L1-L3) were collected in March 2020 according to ISO 5667-3:2018. Probes F1 and F2 were from pigs for fattening, and F3 was from mother pigs.

\subsection{Isolation of Single Bacterial Cultures}

Single colonies, suspected for E. coli, were isolated by ISO 16654:2001/Amd 1:2017 and ISO 9308-1 with some modifications. Enriched samples from faeces and lagoons were cultured on HiCrome ${ }^{\mathrm{TM}}$ Chromogenic Coliform Agar (CCA) (M1991I, HiMedia, Mumbai, India) at $41{ }^{\circ} \mathrm{C}$ for $24 \mathrm{~h}$. For positive controls, we used E. coli ATCC 35218 (American Type Cell Culture Collection, Manassas, VA, USA) and E. coli O:157 (Collection of the Stephan Angeloff Institute of Microbiology). All isolated colonies were morphologically characterized by automatic HD colony counter Scan 1200 (INTERSCIENCE, Saint-Nom-laBretèche, France).

\subsection{Biochemical Characterization}

All isolated single colonies suspected for E. coli were tested for indole production from trypthophan deamination using Kovacs' Indole Reagent (R008, HiMedia, Mumbai, India). We used automatic BD PhoenixTM M50 system (443624, Becton, Dickinson and Company, Franklin Lakes, NJ, USA) for a full biochemical characterization of isolates by the laboratory procedure, as described by the manufacturer. Briefly, the bacterial colonies ( 0.5 McFarland) were inoculated into the ID broth (246001, Becton, Dickinson and Company, Franklin Lakes, NJ, USA), and $25 \mu \mathrm{l}$ were transferred into the AST broth (246003, Becton, Dickinson and Company, Franklin Lakes, NJ, USA) with one drop of an AST indicator solution (246004, Becton, Dickinson and Company, Franklin Lakes, NJ, USA). The suspensions were poured in NMIC/ID-76 panels for Gram-negative bacteria (448103, Becton, Dickinson and Company, Franklin Lakes, NJ, USA) and loaded into the instrument at $35{ }^{\circ} \mathrm{C}$ for $24 \pm 4 \mathrm{~h}$. The obtained data were analyzed by EpiCentre ${ }^{\mathrm{TM}}$ software (V7.45A/V6.71A). The minimum inhibitory concentration (MIC) was determined according to CLSI guidelines.

\subsection{Isolation of $16 S \mathrm{rDNA}$}

The total rDNA was extracted from faecal and lagoon samples with the GeneMATRIX Stool DNA Purification Kit (E3575, EURx Ltd, Gdańsk, Poland). The rDNA concentration and purity were determined with NanoDrop 1000 (Thermo Fisher Scientific Inc., Waltham, MA, USA) by migration in $0.8 \%$ SeaKem ${ }^{\circledR}$ LE Agarose gels (50004L, Lonza Group Ltd, Basel, Switzerland) in a $1 \times$ TBE buffer. The $16 \mathrm{~S}$ rDNA from the confirmed E. coli was isolated with the GenEluteTM Bacterial Genomic DNA Kit (NA2120, Merck (Sigma-Aldrich, St. Louis, MO, USA).

\subsection{PCR Analysis}

The extracted total $16 \mathrm{~S}$ rDNAs from faeces and lagoon samples were subjected to conventional PCR with gene-specific primers for E. coli. The isolated 16S rDNAs from single colonies were subjected to conventional and multiplex PCR with primers linked to virulence and antibiotic resistance genes in the isolated E. coli strains (Table 4). For PCR amplification, we used the Taq PCR Master Mix (2×) protocol (E2520, EURx Ltd, Gdańsk, Poland) being optimized in our laboratory as follows: 1 cycle of initial denaturation running at $95^{\circ} \mathrm{C}$ for $5 \mathrm{~min}$; total 25 cycles of denaturation (at $94{ }^{\circ} \mathrm{C}$ for $30 \mathrm{~s}$ ), annealing (depending on the temperature of the primer for $60 \mathrm{~s}$ ) and extension (at $72{ }^{\circ} \mathrm{C}$ for $1 \mathrm{~min}$ ); 1 cycle of final extension (at $72{ }^{\circ} \mathrm{C}$ for $7 \mathrm{~min}$ ) and cooling $\left(\right.$ at $4{ }^{\circ} \mathrm{C}$ ). The PCR products were visualized in 
$1.5 \%$ agarose gels. For positive controls, we used the following strains: E. coli O:157 for the detection of E. coli strains, E. coli ATCC 43887 for the detection of eae genes, E. coli ATCC 35401 containing LT, Enterococcus faecalis V347 DSM 8629 containing ermB, Enterobacter hormaechei subsp. xiangfangensis DSM 46348 containing ampC, Klebsiella pneumonia DSM 16609 containing blaSHV-5, E. coli ATCC 35218 containing blaTEM, and Citrobacter sp. DSM 30042 containing the $P M Q R$ gene (qnrB60).

Table 4. List of primers used in this study with their sequences.

\begin{tabular}{|c|c|c|}
\hline Primers & Sequences & Reference \\
\hline E. coli $16 \mathrm{~S}$ rDNA F & 5'-AGA GTT TGA TCC TGG CTC AG-3' & \multirow{2}{*}{ [28] } \\
\hline E. coli $16 \mathrm{~S}$ rDNA R & 5'-CTT GTG CGG GCC CCC GTC AAT TC-3' & \\
\hline st $x 1-1 \mathrm{~F}$ & 5'-TTA GAC TTC TCG ACT GCA AAG-3' & \multirow{2}{*}[29,30]{} \\
\hline stx $1-1 \mathrm{R}$ & 5'-TGT TGT ACG AAA TCC CCT CTG-3' & \\
\hline stx2all-1 F & 5'-TTA TAT CTG CGC CGG GTC TG-3' & \multirow{2}{*}[30]{} \\
\hline stx2all-2 R & 5'-AGA CGA AGA TGG TCA AAA CG-3' & \\
\hline LT1 F & 5'-TTA CGG CGT TAC TAT CCT CTC TA-3' & \multirow{2}{*}{ [31] } \\
\hline LT2 R & 5'-GGT CTC GGT CAG ATA TGT GAT TC-3' & \\
\hline STa1 F & 5'-TCC CCT CTT TTA GTC AGT CAA CTG-3' & \multirow{2}{*}{ [31] } \\
\hline STa2 R & 5'-GCA CAG GCA GGA TTA CAA CAA AGT-3' & \\
\hline F4-1 F & 5'-ATC GGT GGT AGT ATC ACT GC-3' & \multirow{2}{*}{ [31] } \\
\hline F4-2 R & 5'-AAC CTG CGA CGT CAA CAA GA-3' & \\
\hline eae (Intimin)-1 F & 5'-CAT TAT GGA ACG GCA GAG GT-3' & \multirow{2}{*}[30,32]{} \\
\hline eae (Intimin)-2 R & 5'-ATC TTC TGC GTA CTG CGT TCA-3' & \\
\hline$q n r \mathrm{~A} \mathrm{~F}$ & 5'-GGG TAT GGA TAT TAT TGA TAA AG-3' & \multirow{2}{*}{ [33] } \\
\hline$q n r \mathrm{~A} \mathrm{R}$ & 5'-CTA ATC CGG CAG CAC TAT TTA-3' & \\
\hline$q n r \mathrm{~B} \mathrm{~F}$ & 5'-GAT CGT GAA AGC CAG AAA GG-3' & \multirow{2}{*}{ [34] } \\
\hline$q n r \mathrm{~B} \mathrm{R}$ & 5'-ACG ATG CCT GGT AGT TGT CC-3' & \\
\hline $\operatorname{aac}(3)-\mathrm{IV} \mathrm{F}$ & 5'-CTT CAG GAT GGC AAG TTG GT-3' & \multirow{2}{*}{ [35] } \\
\hline aac(3)-IV R & 5'-TCA TCT CGT TCT CCG CTC AT-3' & \\
\hline blaSHV F & 5'-TCG CCT GTG TAT TAT CTC CC-3' & \multirow{2}{*}{ [36] } \\
\hline blaSHV R & 5'-CGC AGA TAA ATC ACC ACA ATG-3' & \\
\hline blaTEM F & 5'-TCG GGG AAA TGT GCG CG-3' & \multirow{2}{*}[37,38]{} \\
\hline blaTEM R & 5'-TGC TTA ATC AGT GAG GCA CC-3' & \\
\hline $\operatorname{ampC~F}$ & 5'-AAT GGG TTT TCT ACG GTC TG-3' & \multirow{2}{*}[39,40]{} \\
\hline $\operatorname{ampC~R~}$ & 5'-GGG CAG CAA ATG TGG AGC AA-3' & \\
\hline $\operatorname{ampC~F}$ & 5'-GTG ACC AGA TAC TGG CCA CA-3' & \multirow{2}{*}[41]{} \\
\hline $\operatorname{ampC~R~}$ & 5'-TTA CTG TAG CGC CTC GAG GA-3' & \\
\hline erm B F & 5'-GAA AAA GTA CTC AAC CAA ATA-3' & \multirow{2}{*}[42,43]{} \\
\hline ermB R & 5'-AAT TTA AGT ACC GTT AC-3' & \\
\hline erm B F & 5'-GCA TTT AAC GAC GAA ACT GGC T-3' & \multirow{2}{*}[41]{} \\
\hline ermB R & $5^{\prime}$-GAC AAT ACT TGC TCA TAA GTA ATG GT-3' & \\
\hline
\end{tabular}

\subsection{Disc Diffusion Method}

Antimicrobial susceptibility testing was performed according to the protocols of the CLSI [44]. The results were evaluated according to the EUCAST cut-off values [45] using 
antibiotics applicable to the treatment of patients, namely meropenem (10 $\mu \mathrm{g}$, MEM10C) from Mast Group Ltd., UK, penicillin-G (10 U, SD028-1PK), ampicillin (10 $\mu$ g, SD002-1PK), amoxycillin (25 $\mu \mathrm{g}$, SD129-1PK), amoxycillin/clavulanic acid (20/10 $\mu \mathrm{g}$, AUG30C), carbenicillin $(100 \mu \mathrm{g}$, SD004-1PK), cefamandole (30 $\mu \mathrm{g}, \mathrm{SD} 200-1 \mathrm{PK})$, erythromycin (15 $\mu \mathrm{g}$, SD013-1PK), clarithromycin (15 $\mu \mathrm{g}$, SD192-1PK), streptomycin (10 $\mu \mathrm{g}$, SD031-1PK), tetracycline (30 $\mu \mathrm{g}$, SD037-1PK), doxycycline hydrochloride (30 $\mu \mathrm{g}$, SD012-1PK), chloramphenicol

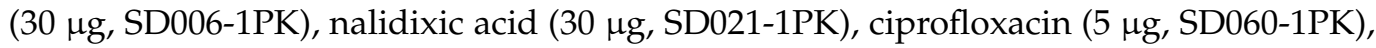
pefloxacin (5 $\mu \mathrm{g}$, SD070-1PK), and co-trimoxazole ( $25 \mu \mathrm{g}$, SD010-1PK) from HiMedia, India.

\subsection{Test for Biofilm Formation}

The ability of the isolated single colonies from pig faeces and lagoons to form biofilms was tested in flat-bottomed 96-well plates, according to the protocol of Stepanović et al. with small modification [46]. Briefly, we used a Brain Heart Infusion broth (M210, HiMedia, India) supplemented with 2\% D-(+)-glucose (G7021, Merck, Darmstadt, Germany). The bacterial inoculums were cultured at $37^{\circ} \mathrm{C}$ for $18 \mathrm{~h}$, and then, the supernatants were aspirated gently. The cells were washed two times with $200 \mu \mathrm{l}$ PBS and fixed with methanol (32213-M; Sigma-Aldrich, USA) for $15 \mathrm{~min}$. The plates were placed to dry; each well was stained with a $200 \mu \mathrm{l} \%$ gentian violet solution for $5 \mathrm{~min}$ and was washed under running water. As a negative control, we used blank. The test was performed sixfold. The biofilms were photodocumented on microscopic-configuration Nikon Eclipse-Ci-L (Nikon Instruments Europe BV, Netherlands) and then dissolved with a 33\% glacial acetic acid solution. The optical density (OD) was measured at $570 \mathrm{~nm}$ by using an ELISA reader ELx800 (BioTek Instruments, Winooski, Vermont, USA). We used the following classification of Christensen et al. (Table 5) to determine the adherence potential [47]:

Table 5. Correlation between the optical density of samples and bacterial adherence [47].

\begin{tabular}{ll}
\hline Formula & Adherence \\
\hline $\mathrm{OD}_{\text {probe }} \leq \mathrm{OD}_{\text {blank }}$ & non-adherent \\
$\mathrm{OD}_{\text {blank }}<\mathrm{OD}_{\text {probe }} \leq 2 \times \mathrm{OD}_{\text {blank }}$ & weakly adherent \\
$2 \times \mathrm{OD}_{\text {blank }}<\mathrm{OD}_{\text {probe }} \leq 4 \times \mathrm{OD}_{\text {blank }}$ & moderately adherent \\
$4 \times \mathrm{OD}_{\text {blank }}<\mathrm{OD}_{\text {probe }}$ & strongly adherent \\
\hline
\end{tabular}

\section{Conclusions}

From the total of 28 single colonies, 16 isolates $(100 \%)$ were confirmed with BD Phoenix M50 and 16S rDNA PCR to be E. coli. The antimicrobial tests showed that most of them $(87.5 \%)$ had MDR. Moreover, $31.25 \%$ of the E. coli strains were capable of forming strong biofilms. We found high percents of resistance varying between $50 \%$ and $75 \%$ to amoxicillin, ampicillin, tetracycline, and chloramphenicol. The resistances $(25 \%-50 \%)$ to clinically administered antibiotics, such as trimethoprim, trimethoprim/sulfamethoxazole, doxycycline hydrochloride, and nalidixic acid, were no less. We proved the $\beta$-lactamase genes blaTEM/blaSHV in one isolate from lagoon and ampC in three isolates from pigs for fattening and in four isolates from lagoons.

From the results presented here and compared with the data for the period 2012-2016, high resistance to tetracycline was found in growing pigs and fattening swine, which is a worrying fact as coliforms resistant to this antibiotic may be ingested during consumption. This also applies to the antibiotics ampicillin and amoxicillin, which continue to be used in veterinary practice. Probably, less commonly applied are streptomycin, erythromycin, and doxycycline. Considering the clinical importance of antibiotic resistance emergence in veterinary and human medicine, the prescription of antibiotics should be carefully monitored and regulated, in order to reduce AMR in food industry in Bulgaria. 
Author Contributions: Conceptualization, L.D., M.M.Z., and H.N.; methodology, L.D. and M.K.; investigation, L.D., M.K., M.M.Z., C.S., I.T., M.A., V.K., Y.I., and S.N.; data curation, L.D.; writingoriginal draft preparation, L.D.; writing-review and editing, H.N. All authors have read and agreed to the published version of the manuscript.

Funding: This research was funded by the National Fund for Scientific Research, Republic of Bulgaria (grant number: KP-06-N36/7 from 13 December 2019).

Institutional Review Board Statement: Not applicable.

Informed Consent Statement: Not applicable.

Data Availability Statement: The data presented in this study are available on request from the corresponding author.

Conflicts of Interest: The authors declare no conflict of interest.

\section{References}

1. O'neill, J.I.M. Antimicrobial resistance: Tackling a crisis for the health and wealth of nations. Rev. Antimicrob. Resist 2014, $20,1-16$.

2. He, L.-Y.; He, L.-K.; Liu, Y.-S.; Zhang, M.; Zhao, J.-L.; Zhang, Q.-Q.; Ying, G.-G. Microbial diversity and antibiotic resistome in swine farm environments. Sci. Total Environ. 2019. [CrossRef]

3. Wellington, E.M.; Boxall, A.B.; Cross, P.; Feil, E.J.; Gaze, W.H.; Hawkey, P.M.; Johnson-Rollings, A.S.; Jones, D.L.; Lee, N.M.; Otten, $\mathrm{W}$. The role of the natural environment in the emergence of antibiotic resistance in Gram-negative bacteria. Lancet Infect. Dis. 2013, 13, 155-165. [CrossRef]

4. Storteboom, H.; Arabi, M.; Davis, J.; Crimi, B.; Pruden, A. Identification of antibiotic-resistance-gene molecular signatures suitable as tracers of pristine river, urban, and agricultural sources. Environ. Sci. Technol. 2010, 44, 1947-1953. [CrossRef] [PubMed]

5. Winkworth-Lawrence, C.; Lange, K. Antibiotic resistance genes in freshwater biofilms may reflect influences from high-intensity agriculture. Microb. Ecol. 2016, 72, 763-772. [CrossRef]

6. Marti, E.; Variatza, E.; Balcazar, J.L. The role of aquatic ecosystems as reservoirs of antibiotic resistance. Trends Microbiol. 2014, 22, 36-41. [CrossRef]

7. Prescott, J.F. The resistance tsunami, antimicrobial stewardship, and the golden age of microbiology. Vet. Microbiol. 2014, 171, 273-278. [CrossRef]

8. Garner, E.; Benitez, R.; von Wagoner, E.; Sawyer, R.; Schaberg, E.; Hession, W.C.; Krometis, L.-A.H.; Badgley, B.D.; Pruden, A. Stormwater loadings of antibiotic resistance genes in an urban stream. Water Res. 2017, 123, 144-152. [CrossRef]

9. Yu, Z.; He, P.; Shao, L.; Zhang, H.; Lü, F. Co-occurrence of mobile genetic elements and antibiotic resistance genes in municipal solid waste landfill leachates: A preliminary insight into the role of landfill age. Water Res. 2016, 106, 583-592. [CrossRef] [PubMed]

10. Sarowska, J.; Futoma-Koloch, B.; Jama-Kmiecik, A.; Frej-Madrzak, M.; Ksiazczyk, M.; Bugla-Ploskonska, G.; Choroszy-Krol, I. Virulence factors, prevalence and potential transmission of extraintestinal pathogenic Escherichia coli isolated from different sources: Recent reports. Gut Pathog. 2019, 11, 10. [CrossRef]

11. Luppi, A. Swine enteric colibacillosis: Diagnosis, therapy and antimicrobial resistance. Porc. Health Manag. 2017, 3 , 1-18. [CrossRef]

12. Pereira, D.A.; Vidotto, M.C.; Nascimento, K.A.; Santos, A.C.R.d.; Mechler, M.L.; Oliveira, L.G.d. Virulence factors of Escherichia coli in relation to the importance of vaccination in pigs. Ciência Rural 2016, 46, 1430-1437. [CrossRef]

13. Loos, M.; Geens, M.; Schauvliege, S.; Gasthuys, F.; van der Meulen, J.; Dubreuil, J.D.; Goddeeris, B.M.; Niewold, T.; Cox, E. Role of heat-stable enterotoxins in the induction of early immune responses in piglets after infection with enterotoxigenic Escherichia coli. PLoS ONE 2012, 7, e41041. [CrossRef]

14. Nataro, J.P.; Kaper, J.B. Diarrheagenic Escherichia coli. Clin. Microbiol. Rev. 1998, 11, 142-201. [CrossRef]

15. Fairbrother, J.; Gyles, C. Post-weaning Escherichia coli diarrhea and edema disease. In Diseases of Swine; Straw, B.E., Zimmerman, J.J., D’Allaire, S., Taylor, D.J., Eds.; Blackwell Publishing: Hoboken, NJ, USA, 2006.

16. Dubreuil, J.D.; Isaacson, R.E.; Schifferli, D.M. Animal enterotoxigenic Escherichia coli. EcoSal Plus 2016, 7, 1-80. [CrossRef]

17. Blanco, M.; Blanco, J.E.; Dahbi, G.; Mora, A.; Alonso, M.P.; Varela, G.; Gadea, M.P.; Schelotto, F.; Gonzalez, E.A.; Blanco, J. Typing of intimin (eae) genes from enteropathogenic Escherichia coli (EPEC) isolated from children with diarrhoea in Montevideo, Uruguay: Identification of two novel intimin variants ( $\mu \mathrm{B}$ and $\xi \mathrm{R} / \beta 2 \mathrm{~B})$. J. Med. Microbiol. 2006, 55, 1165-1174. [CrossRef]

18. Beutin, L.; Zimmermann, S.; Gleier, K. Evaluation of the VTEC-Screen "Seiken" test for detection of different types of Shiga toxin (verotoxin)-producing Escherichia coli (STEC) in human stool samples. Diagn. Microbiol. Infect. Dis. 2002, 42, 1-8. [CrossRef]

19. EFSA; ECDC. The European Union one health 2018 zoonoses report. EFSA J. 2019, 17, e05926.

20. ECDC. Antimicrobial resistance surveillance in Europe 2016. In Annual Report of the European Antimicrobial Resistance Surveillance Network (EARS-Net); ECDC: Stockholm, Sweden, 2017.

21. WHO. Central Asian and Eastern European Surveillance of Antimicrobial Resistance; WHO: Geneva, Switzerland, 2019. 
22. ECDC. Surveillance of Antimicrobial Resistance in Europe. In Annual Report of the European Antimicrobial Resistance Surveillance Network (EARS-Net) 2017; ECDC: Stockholm, Sweden, 2018.

23. Buranasinsup, S.; Kulpeanprasit, S.; Kong-ngoen, T.; Jangsangthong, A.; Sookrung, N.; Chaicumpa, W.; Indrawattana, N. Prevalence of the Multi-drug Resistance of Shiga Toxin-producing Escherichia coli Isolated from Pigs in Central Thailand. Chiang Mai J. Sci 2018, 45, 21-32.

24. Urumova, V. Phenotypic and Genotypic Characteristics of Antimicrobial Resistance in Resident Escherichia coli and Enterococcus spp., Isolated from Intensively Farmed Pigs in Bulgaria (in Bulgarian); Trakia University: Stara, Zagora, 2016.

25. Hu, Y.S.; Shin, S.; Park, Y.H.; Park, K.T. Prevalence and mechanism of fluoroquinolone resistance in Escherichia coli isolated from swine feces in Korea. J. Food Prot. 2017, 80, 1145-1151. [CrossRef] [PubMed]

26. Cheng, P.; Yang, Y.; Li, F.; Li, X.; Liu, H.; Fazilani, S.A.; Guo, W.; Xu, G.; Zhang, X. The prevalence and mechanism of fluoroquinolone resistance in Escherichia coli isolated from swine farms in China. BMC Vet. Res. 2020, 16, 258. [CrossRef]

27. Dimitrova, A.; Yordanov, S.; Petkova, K.; Savova, T.; Bankova, R.; Ivanova, S. Example scheme for antibacterial therapy and metaphylaxis of colibacillosis in the intensive pig production (in Bulgarian). Livest. Science. Agric. Acad. 2016, LIII, 44-53.

28. Magray, M.S.U.D.; Kumar, A.; Rawat, A.K.; Srivastava, S. Identification of Escherichia coli through analysis of $16 \mathrm{~S}$ rRNA and 16S-23S rRNA internal transcribed spacer region sequences. Bioinformation 2011, 6, 370. [CrossRef]

29. Padola, N.L.; Sanz, M.E.; Blanco, J.E.; Blanco, M.; Blanco, J.; Etcheverria, A.I.; Arroyo, G.H.; Usera, M.A.; Parma, A.E. Serotypes and virulence genes of bovine Shigatoxigenic Escherichia coli (STEC) isolated from a feedlot in Argentina. Vet. Microbiol. 2004, 100, 3-9. [CrossRef]

30. Byun, J.; Jung, B.; Kim, H.; Fairbrother, J.; Lee, M.; Lee, W. O-serogroups, virulence genes of pathogenic Escherichia coli and Pulsedfield gel electrophoresis (PFGE) patterns of O149 isolates from diarrhoeic piglets in Korea. Vet. Med. 2013, 58, 468-476. [CrossRef]

31. Memon, J.; Kashif, J.; Hussain, N.; Yaqoob, M.; Ali, A.; Buriro, R.; Soomro, J.; Hassan, M.F.; Sahito, B.; Hongjie, F. Serotypes, Genotypes, Virulence Factors and Antimicrobial Resistance Genes of Escherichia coli Isolated in Bovine Clinical Mastitis from Eastern China. Pak. Vet. J. 2016, 36.

32. Do, K.-H.; Byun, J.-W.; Lee, W.-K. Virulence genes and antimicrobial resistance of pathogenic Escherichia coli isolated from diarrheic weaned piglets in Korea. J. Anim. Sci. Technol. 2020, 62, 543. [CrossRef] [PubMed]

33. Annisha, O.D.R.; Li, Z.; Zhou, X.; Stenay Junior, N.M.D.; Donde, O.O. Efficacy of integrated ultraviolet ultrasonic technologies in the removal of erythromycin-and quinolone-resistant Escherichia coli from domestic wastewater through a laboratory-based experiment. J. Water Sanit. Hyg. Dev. 2019, 9, 571-580. [CrossRef]

34. Pourhossein, Z.; Asadpour, L.; Habibollahi, H.; Shafighi, S.T. Antimicrobial resistance in fecal Escherichia coli isolated from poultry chicks in northern Iran. Gene Rep. 2020, 21, 100926. [CrossRef]

35. Ranjbar, R.; Dehkordi, F.S.; Shahreza, M.H.S.; Rahimi, E. Prevalence, identification of virulence factors, O-serogroups and antibiotic resistance properties of Shiga-toxin producing Escherichia coli strains isolated from raw milk and traditional dairy products. Antimicrob. Resist. Infect. Control 2018, 7, 53. [CrossRef]

36. Jafari, E.; Mostaan, S.; Bouzari, S. Characterization of antimicrobial susceptibility, extended-spectrum $\beta$-lactamase genes and phylogenetic groups of enteropathogenic Escherichia coli isolated from patients with diarrhea. Osong Public Health Res. Perspect. 2020, 11, 327. [CrossRef] [PubMed]

37. Huang, Y.-H.; Kuan, N.-L.; Yeh, K.-S. Characteristics of extended-spectrum $\beta$-lactamase-producing Escherichia coli from dogs and cats admitted to a Veterinary Teaching Hospital in Taipei, Taiwan From 2014 to 2017. Front. Vet. Sci. 2020, 7, 395. [CrossRef] [PubMed]

38. Abimiku, R.H.; Ngwai, Y.B.; Nkene, I.H.; Bassey, B.E.; Tsaku, P.A.; Ibrahim, T.; Tama, S.C.; Ishaleku, D.; Pennap, G.R.I. Molecular Diversity and extended spectrum beta-lactamase resistance of diarrheagenic Escherichia coli from patients attending selected health care facilities in Nasarawa state, Nigeria. Int. J. Pathog. Res. 2019, 3, 1-18. [CrossRef]

39. Khoirani, K.; Indrawati, A.; Setiyaningsih, S. Detection of ampicillin resistance encoding gene of Escherichia coli from chickens in Bandung and Purwakarta. J. Ris. Vet. Indones. (J. Indones. Vet. Res.) 2019, 3. [CrossRef]

40. Kim, Y.W.; Choe, J.C.; Jablonski, P.G. Detection of antibiotic-resistant Escherichia coli from the feces of the Oriental magpie nestlings. J. Korean Soc. Ornithol. 2020, 27, 3-9. [CrossRef]

41. Böckelmann, U.; Dörries, H.-H.; Ayuso-Gabella, M.N.; de Marçay, M.S.; Tandoi, V.; Levantesi, C.; Masciopinto, C.; Van Houtte, E.; Szewzyk, U.; Wintgens, T. Quantitative PCR monitoring of antibiotic resistance genes and bacterial pathogens in three European artificial groundwater recharge systems. Appl. Environ. Microbiol. 2009, 75, 154-163. [CrossRef]

42. Nguyen, M.C.P.; Woerther, P.-L.; Bouvet, M.; Andremont, A.; Leclercq, R.; Canu, A. Escherichia coli as reservoir for macrolide resistance genes. Emerg. Infect. Dis. 2009, 15, 1648. [CrossRef] [PubMed]

43. Hassanen, F.; Sabike, I.; Haikel, G.; Elged, E. Screening for Antimicrobial resistance in some pathogens isolated from cold smoked fish marketed in Menofiya government. Benha Vet. Med. J. 2018, 35, 269-283. [CrossRef]

44. CLSI. Performance Standards for Antimicrobial Disk and Dilution Susceptibility Tests for Bacteria Isolated from Animals, 3rd ed.; Approved Standard; Clinical and Laboratory Standards Institute: Wayne, PA, USA, 2009.

45. EUCAST. European Committee on Antimicrobial Susceptibility Testing. Breakpoint Tables for Interpretation of MICs and Zone Diameters. Version 10.0. 2020. Available online: https:/ / eucast.org/clinical_breakpoints/ (accessed on 2 August 2021). 
46. Stepanović, S.; Vuković, D.; Dakić, I.; Savić, B.; Švabić-Vlahović, M. A modified microtiter-plate test for quantification of staphylococcal biofilm formation. J. Microbiol. Methods 2000, 40, 175-179. [CrossRef]

47. Christensen, G.D.; Simpson, W.A.; Younger, J.; Baddour, L.; Barrett, F.; Melton, D.; Beachey, E. Adherence of coagulase-negative staphylococci to plastic tissue culture plates: A quantitative model for the adherence of staphylococci to medical devices. J. Clin. Microbiol. 1985, 22, 996-1006. [CrossRef] 